ORIGINAL ARTICLE / ARTIGO ORIGINAL

\title{
Vitamin A status and associated factors in infants attending at Primary Health Care in Goiânia, Goiás, Brazil
}

\author{
Estado nutricional de vitamina $A$ e fatores associados em lactentes \\ atendidos em Unidades Básicas de Saúde de Goiânia, Goiás, Brasil \\ Lara Lívia Santos da Silva', Maria do Rosário Gondim Peixoto", \\ Maria Claret Costa Monteiro Hadler", Sara Araújo da Silva"l', Fernanda Cobayashi"v, \\ Marly Augusto Cardosov
}

\begin{abstract}
Objective: This study aimed to assess the nutritional status of vitamin A and associated factors in children assisted in Primary Care Health in Goiânia, Goiás, Brazil. Methods: This is a cross-sectional study with a sample of 228 children 12 to 16 months of age. The nutritional status of vitamin A was assessed by serum retinol concentration, determined by high performance liquid chromatography. Multiple linear regression models with hierarchical selection of independent variables were used to evaluate the correlation with serum retinol as the dependent variable. Results: The vitamin A deficiency (retinol $<0,7 \mu \mathrm{mol} / \mathrm{L}$ ) was observed in $14,0 \%$ of the children. Maternal schooling and hemoglobin concentration were positively correlated with serum retinol concentration, while $C$-reactive protein showed a negative correlation $\left(R^{2}=0,1648\right)$. Conclusion: The vitamin A deficiency in one-year-old children attended in Basic Health Units in Goiânia configures itself as a moderate public health problem. Actions to promote maternal education, morbidity control and prevention of other micronutrient deficiencies are important for prevention and control of the vitamin A deficiency in this population.
\end{abstract}

Keywords: Vitamin A. Micronutrients. Infant. Child health. Nutritional status. Primary health care.

'Graduate Program in Nutrition and Health, School of Nutrition, Universidade Federal de Goiás - Goiânia (GO), Brazil.

"School of Nutrition, Universidade Federal de Goiás - Goiânia (GO), Brazil.

"'General Coordination of Food and Nutrition, Ministry of Health - Brasília (DF), Brazil.

IvGraduate Program in Public Health Nutrition, Public Health School, Universidade de São Paulo - São Paulo (SP), Brazil.

vDepartment of Nutrition, Public Health School, Universidade de São Paulo - São Paulo (SP), Brazil

Corresponding author: Maria do Rosário Gondim Peixoto. Faculdade de Nutrição da Universidade Federal de Goiás. Rua 227. quadra 68, s/n, Setor Leste Universitário, CEP 74605-080, Goiânia, G0, Brasil. E-mail: mrg.peixoto@uol.com.br

Conflict of interests: nothing to declare - Financial support: Research financed by the Ministry of Health, General Coordination of Food and Nutrition; administrative and financial management of the National Council for Scientific and Technological Development (CNPq), process n. 552747/2011-4). Masters scholarship of Lara Lívia Santos da Silva, from the Coordination for the Improvement of Higher Education Personnel (CAPES).

Members of the National Study Fortificação Caseira da Alimentação Complementar (ENFAC Working Group): Marly Augusto Cardoso, Rosângela Aparecida Augusto, Fernanda Cobayashi (Department of Nutrition, Universidade de São Paulo); Maria Claret C. M. Hadler, Maria do Rosário G. Peixoto (School of Nutrition, Universidade Federal de Goiás), Pedro Israel C. Lira, Leopoldina Augusta S. Sequeira (Department of Nutrition, Universidade Federal de Pernambuco), Pascoal Torres Muniz, Cristiéli Sérgio de Menezes Oliveira (Center of Health Sciences, Universidade Federal do Acre), Márcia Regina Vitolo, Daniela Cardoso Tietzmann (Universidade Federal de Ciências da Saúde de Porto Alegre), Márcia Maria Tavares Machado (Department of Preventive Medicine, Universidade Federal do Ceará), Patrícia Constante Jaime, Eduardo Augusto Fernandes Nilson, Gisele Ane Bortolini, Sara Araújo da Silva (General Coordination of Food and Nutrition, Ministry of Health in Brazil).

490

REV BRAS EPIDEMIOL APR-JUN 2015; 18(2): 490-502 
RESUMO: Objetivo: Este estudo teve por objetivo avaliar o estado nutricional de vitamina A e fatores associados em crianças atendidas em Unidades Básicas de Saúde de Goiânia, Goiás. Métodos: Trata-se de estudo transversal com amostra composta por 228 crianças de 12 a 16 meses de idade. O estado nutricional de vitamina A foi avaliado pela concentração sérica de retinol, determinada por cromatografia líquida de alta resolução. Modelos de regressão linear múltiplos com seleção hierárquica de variáveis independentes foram utilizados para avaliar a correlação com a concentração sérica de retinol como variável dependente. Resultados: A deficiência de vitamina A (retinol < 0,7 $\mu \mathrm{mol} / \mathrm{L}$ ) foi observada em 14,0\% das crianças. A escolaridade materna e a concentração de hemoglobina apresentaram correlação positiva com a concentração sérica de retinol, enquanto a proteína C-reativa apresentou correlação negativa $\left(\mathrm{R}^{2}=0,1648\right)$. Conclusão: A deficiência de vitamina A em crianças de um ano atendidas em Unidades Básicas de Saúde de Goiânia configura-se como um problema de saúde pública moderado. Medidas de incentivo à maior escolaridade materna, controle de morbidades e prevenção de carências de outros micronutrientes são importantes para prevenção e controle da deficiência de vitamina A nessa população.

Palavras-chave: Vitamina A. Micronutrientes. Lactente. Saúde da criança. Estado nutricional. Atenção primária à saúde.

\section{INTRODUCTION}

Vitamin A deficiency (VAD) is one of the main nutritional deprivations in childhood, affecting approximately 190 million preschoolers around the world ${ }^{1}$. In Brazil, according to the National Research on Demography and Health, conducted in $2006,17.4 \%$ of the children aged less than 5 years old presented with VAD, mostly in the Center-West region $(11.8 \%)^{2}$, which, according to the World Health Organization (WHO), represents a moderate public health problem in this region ${ }^{1}$.

A study carried out in municipal daycare facilities in Goiânia, Goiás, with children aged from 6 to 24 months old, found $21.7 \%^{3}$ prevalence of VAD. Other studies conducted in different cities of the country, including children aged less than 2 years old, found prevalence rates ranging from 9.6 to $39.6 \%{ }^{4-7}$.

VAD is the main cause of avoidable blindness in childhood, and contributes with the increasing number of deaths and infectious diseases among children because it reduces the immune resistance to diseases such as diarrhea and measles ${ }^{1}$. The low concentrations of vitamin A among children aged less than two years old can be caused by inadequate complementary diet, characterized by the non-offer of breast milk, inopportune introduction of complementary diet, or the latter not contemplating sources of vitamin $\mathrm{A}^{8}$. Besides, frequent infections are associated with low concentrations of serum retinol, poor absorption and increasing catabolism of this vitamin ${ }^{8,9}$.

Other factors may be associated with the retinol concentration in childhood, such as socioeconomic and environmental conditions ${ }^{10-13}$, maternal characteristics, like mother's age and number of prenatal appointments ${ }^{14}$, and anthropometric features of the child, 
such as birth weight ${ }^{15}$ and anthropometric indexes ${ }^{11,16}$. However, these factors are still controversial in literature ${ }^{17,18}$.

The main actions of food and nutrition addressed to the prevention and control of vitamin A deficiency are the periodical supplementation with megadoses of vitamin A, food fortification and dietary changes and diversification ${ }^{1}$. In Brazil, the main action is promoted by the National Program of Vitamin A Supplementation, created in 1983, which distributes megadoses of vitamin A for children aged from 6 to 59 months old ${ }^{19}$. At first, this program only involved the regions with higher prevalence of VAD in the country; however, in 2012 it was amplified and, after December 2012, it began to work in the Basic Health Units (UBS) of Goiânia, Goiás.

Knowing the nutritional status of vitamin A and its associated factors among children attending the UBS is important to clarify the factors that are associated with this deficiency in childhood, as well as to guide the implementation of public policies tha can improve the National Program of Vitamin A Supplementation, which was recently established in Goiânia. This way, it becomes more efficient to solve this problem. Therefore, the objective of this study was to assess the nutritional status of vitamin A and its associated factors among 1-year-olds assisted at UBSs in Goiânia, Goiás.

\section{METHODOLOGY}

This cross-sectional study is part of a pragmatic clinical trial called "Effectiveness of home fortification with vitamins and minerals for the prevention of iron deficiency and anemia in infants younger than 1 year of age: a multi-center study of Brazilian cities".

The study sample was composed of participants in the control group, with children aged from 12 to 16 months old, from both genders, assisted at the child-care center in 12 UBSs in the city of Goiânia, Goiás, from June, 2012, to February, 2013. The study excluded premature children, twins, with malaria, HIV, tuberculosis, hemoglobinopathies and the ones being treated for anemia at the time of the study.

The sample size was calculated for the main study. The main outcome was considered to be the increasing mean concentration of blood hemoglobin. For $95 \%$ power and $5 \%$ significance level (bicaudal), 105 children were in each group to detect a $6 \mathrm{~g} / \mathrm{L}$ difference between the means of hemoglobin, with estimated standard-deviation of $12 \mathrm{~g} / \mathrm{L}^{20}$. The sample predicted for the city of Goiannia contemplated twice the sample. For the control group, 210 children were necessary, and more $30 \%$ to cover for possible losses and refusals; therefore, the sample comprised 270 children. The study included 303 children, however, 70 did not collect blood. The reasons for that were parents giving up the participation $(\mathrm{n}=62)$, loss of contact with the child $(\mathrm{n}=5)$, and children who were older than the analyzed age group $(n=3)$. The blood samples of five children were not sufficient for the evaluation of serum retinol, resulting in a final 
sample of 228 children. This sample size allowed the detection of 0.20 correlation, with $80 \%$ power and 0.05 significance level ${ }^{20}$.

The team in the field was composed of nutritionists and graduate students at the School of Nutrition at Universidade Federal de Goiás and Pontifícia Universidade Católica de Goiás. After the team was trained, interviewers went to the UBSs participating in the study, and after the identification and explanation of the study's objectives, mothers or people in charge of the children were invited to voluntarily participate in the research by signing the informed consent. A structured questionnaire was used to collect data regarding socioeconomic, demographic, and maternal conditions, as well as breast milk, and use of vitamin A and D supplementation by the child.

Weight and length measurements of the children were obtained in duplicate and sequentially, by using standardized procedures ${ }^{21}$. Satisfactory measurements where those in which the maximum weight variation was of 100 grams; and length, $0.5 \mathrm{~cm}$. The mean value of both measurements was analyzed. Weight was measured with an electronic scale from WISO, model@-835, capacity for $180 \mathrm{~kg}, 100 \mathrm{~g}$ grading. The children were weighed and measured naked, at the presence of the mother or person in charge. Weight was measured with the mother holding the child and, then, the weight of the mother was discounted. Length was assessed by a portable infantometer from Sanny, model ES-2000, with $1 \mathrm{~m}$ extension and $1 \mathrm{~mm}$ accuracy. Children were measured in dorsal decubitus, on a flat surface, and the value was registered in centimeters. The $Z$ scores of body mass index/age and height/age were obtained by using the WHO anthro software, version 3.2.2. Z scores $\geq 4$ e $\leq-4$ in both analyzed anthropometric indexes were excluded from the analysis.

Blood was collected by properly trained professional, and collection was schedule up to a week after the interview. It took place in the household, laboratory or UBS, according to the preference of the people in charge of the child. Samples of up to $10 \mathrm{~mL}$ of venous blood were collected from the children, early in the morning, with minimum fasting time of three hours. Blood hemoglobin was determined at the time of blood collection by a portable hemoglobinometer from Hemocue. The volume of obtained blood was stored in a dry test tube to obtain the serum, protected from the light, and in a tube with EDTA to obtain the plasma. After clot retraction, the blood was centrifuged at 3,000 rotations per minute and blood samples were separated in microtubes, being frozen at $-20^{\circ} \mathrm{C}$ until being transported to the laboratory of Human Nutrition in the Department of Nutrition of the Public Health School at Universidade de São Paulo. There, they were stored at $-70^{\circ} \mathrm{C}$ until the conduction of biochemical analyses. For the determination of serum retinol, an aliquot of about $1.5 \mathrm{~mL}$ of serum was maintained in an ambar microtube, and, for the analysis of C-reactive protein (CRP), $500 \mu \mathrm{L}$ of plasma were placed in a transparent microtube.

Serum retinol was analyzed by high-resolution liquid chromatography (HPLC-110, Hewlett-Packard, United States $)^{22}$ and the plasmatic determination of CRP was conducted by 
an ultra-sensitive method (chemiluminescence). Children with serum retinol concentrations lower than $1.05 \mu \mathrm{mol} / \mathrm{L}$ and $0.7 \mu \mathrm{mol} / \mathrm{L}$ were considered to have vitamin A insufficiency and deficiency, respectively ${ }^{23}$. The presence of subclinical infection was assessed by CRP values $>5 \mathrm{mg} / \mathrm{L}^{24}$. Data were doubly typed using the software Epi Info 5.3.1 for Windows. After typing, the bank was converted to the software Stata, version 12.0 for data processing and analysis. The normality of continuous variables was analyzed by the Shapiro-Wilk test. For the characterization of the sample, absolute and relative frequencies were calculated for the categorical variables; mean and standard-deviation, for continuous variables with normal distribution; and median and interquartile interval for the variables without normal distribution. Differences in the prevalence of VAD were analyzed by the Pearson's $\chi^{2}$ test.

The independent variables selected for this study were gender (male/female), age of the child in months, per capita income in reais, maternal schooling in years, treatment of drinking water, categorized as inadequate (untreated or chlorinated) and adequate (filtered, boiled or mineral), sanitary sewer (without public network/with public network), number of children aged less than five years old in the house $(1 \mathrm{child} / \mathrm{more}$ than 1 child), maternal age in years, number of prenatal appointments, weight at birth in kilograms, body mass index per age (BMI/age) and height per age in Z score, age of weaning in days, use of vitamin A and D supplements (never used them/has used them or still does), diarrhea in the past 15 days (yes/no), hemoglobin in $\mathrm{g} / \mathrm{dL}$ and CRP in $\mathrm{mg} / \mathrm{L}$. The serum retinol concentration in $\mu \mathrm{mol} / \mathrm{L}$ was considered as a dependent variable, in the logarithm base, to meet the presupposition of normal distribution.

To estimate the effect of independent variables on the outcome of interest, multiple linear regression models with hierarchical selection of variables were used, as proposed by Victora et al. ${ }^{25}$. A theoretical model to determine VAD was previously elaborated: the selected independent variables were grouped in three blocks, ordered according to the influence on the outcome. The most distal block was composed of sociodemographic variables (age, gender, per capita income and maternal schooling); the intermediate block had environmental variables (treatment of drinking water, sanitary sewer and number of children aged less than five years old in the house) and maternal variables (maternal age and number of prenatal appointments); and the proximal block, with variables related to the child, such as anthropometric variables (weight at birth, BMI/age and height/age), related to breastfeeding/supplementation (age of weaning and vitamin A and D supplementation) and presence of morbidities (diarrhea in the past 15 days, hemoglobin and CRP).

At first, linear regression models adjusted by age and gender and were analyzed for the selection of variables to be tested in multiple models ( $p \leq 0.20$ ). Afterwards, in each block of determination, from the distal to the proximal ones, variables presenting $\mathrm{p}$-values $<0.10$ in the Wald test were removed from the model and tested individually to check if their insertion in the model would improve the coefficient of determination, or they would change the magnitude of the beta coefficient of 
variables in the tested block in more than $10 \%$. Factors associated with the serum retinol concentration were considered to be the variables that, after the adjustment for potential factors in the same block and hierarchically superior blocks, presented $\mathrm{p}$-value $<0.05$ in the final model.

The research protocol was submitted to and approved by the Research Ethics Committees from the Public Health School of Universidade de São Paulo and Universidade Federal de Goiás, protocol n. 2291/2013 and 065/12, respectively. Data collection took place before the consent from the Municipal Secretariat of Health in Goiânia, Goiás.

\section{RESULTS}

The description of the studied population is presented in Table 1 . The study comprised 228 children, being 115 male (50.4\%). The age of the children ranged from 12 to 16 months old, and the median was 14 months.

The per capita income median was $\mathrm{R} \$ 300.00$, and maternal schooling was 11 years. Regarding the environmental characteristics, $56.4 \%$ of sanitary sewer came from the public network, and for $79 \%$ of the children, the treatment of drinking water was adequate. In $77.6 \%$ of the household there was only 1 child younger than 5 . Regarding the data from the mothers, the median age was 27 years old, and the median number of prenatal appointments during pregnancy was 8 .

As to the data related to the children, the mean weight at birth was $3.2 \pm 0.5 \mathrm{~kg}$ and the mean BMI/age and height/age rates were within normal patterns $(0.3 \pm 1.2$ and $0.1 \pm 1.2 \mathrm{Z}$ score, respectively). The median age of weaning was 180 days, and approximately $85 \%$ of the children had never taken vitamin A and D supplementation. Regarding the indicators of morbidity, $23.7 \%$ of the children had diarrhea in the 15 days prior to data collection, the mean of hemoglobin was $12.5 \pm 0.9 \mathrm{~g} / \mathrm{dL}$ and the median CRP was $0.5(0.2-1.7) \mathrm{mg} / \mathrm{L}$.

The median of serum retinol concentration was $1.3(0.9-1.8) \mu \mathrm{mol} / \mathrm{L}$. Vitamin A insufficiency (retinol $<1.05 \mu \mathrm{mol} / \mathrm{L}$ ) was present among $34.2 \%$ of the children (data not shown), and VAD (retinol $<0.7 \mu \mathrm{mol} / \mathrm{L}$ ), among14.0\% (Table 2). Higher

prevalence of VAD was observed among children whose mothers had lower schooling $(\mathrm{p}=0.027)$ and among those with CRP $>5 \mathrm{mg} / \mathrm{L}(\mathrm{p}<0.001)$. The prevalence of subclinical infection (CRP $>5 \mathrm{mg} / \mathrm{L}$ ) was $13.9 \%$. After excluding children with subclinical infection from the analysis, the prevalence of VAD decreases to 9.9, thus representing a $4.1 \%$ overestimation in the general prevalence of VAD (Table 2 ).

Table 3 presents the results of linear regression analyses adjusted for age and gender between the independent variables and serum retinol concentration. For socioeconomic factors, it was possible to observe a positive and significant correlation only for the maternal schooling variable. For environmental and maternal factors, no significant 
correlation was found, and regarding the factors related to the children, the hemoglobin variable was positively correlated with serum retinol concentration, unlike CRP, which was negatively correlated to this outcome. The variables that were tested in multiple models were per capita income, maternal schooling, treatment of drinking water, number of children aged less than 5 years old, maternal age, hemoglobin and CRP, since they presented $\mathrm{p}$-value $\leq 0,20$.

The variables that were maintained in the final multiple model were maternal schooling, hemoglobin and CRP (Table 4). For each year in maternal schooling and for each unit of

Table 1. Characterization of the sample of children assisted in Basic Health Units of Goiânia, Goiás, $2013(n=228)$.

\begin{tabular}{|c|c|}
\hline \multirow{3}{*}{ Variables } & $\mathrm{n}(\%)^{*}$ \\
\hline & median (p25 - p75) \\
\hline & Mean \pm SD \\
\hline \multicolumn{2}{|l|}{ Gender $(n=228)$} \\
\hline Male & $115(50.4)$ \\
\hline Female & $113(49.6)$ \\
\hline Age (months) $(n=228)$ & $14(13-14)$ \\
\hline Per capita income $(R \$)(n=225)$ & $300(200-441.7)$ \\
\hline Maternal schooling (years) $(n=225)$ & $11(8-11)$ \\
\hline \multicolumn{2}{|l|}{ Treatment of drinking water $(n=228)$} \\
\hline Inadequate & $48(21.0)$ \\
\hline Adequate & $180(79.0)$ \\
\hline \multicolumn{2}{|l|}{ Sanitary sewer $(n=227)$} \\
\hline Without public network & $99(43.6)$ \\
\hline With public network & $128(56.4)$ \\
\hline \multicolumn{2}{|l|}{ Children with $<5$ years old in the house $(n=228)$} \\
\hline 1 child & $177(77.6)$ \\
\hline$>1$ child & $51(22.4)$ \\
\hline Mother's age (years) $(n=228)$ & $27(23-32)$ \\
\hline Number of prenatal appointments $(n=214)$ & $8(6-10)$ \\
\hline Weight at birth $(\mathrm{kg})(\mathrm{n}=227)$ & $3.2 \pm 0.5$ \\
\hline Body mass index/age (Z score) $(n=222)$ & $0.3 \pm 1.2$ \\
\hline Height/age index (Z score) $(n=225)$ & $0.1 \pm 1.2$ \\
\hline Age of weaning (days) $(n=105)$ & $180(90-240)$ \\
\hline \multicolumn{2}{|l|}{ Vitamin A and D supplementation $(n=226)$} \\
\hline Never used it & $193(85.4)$ \\
\hline Has used it or uses it & $33(14.6)$ \\
\hline \multicolumn{2}{|l|}{ Diarrhea in the past 15 days $(n=228)$} \\
\hline No & $174(76.3)$ \\
\hline Yes & $54(23.7)$ \\
\hline Hemoglobin $(\mathrm{g} / \mathrm{dL})(\mathrm{n}=227)$ & $12.5 \pm 0.9$ \\
\hline C-reactive protein $(\mathrm{mg} / \mathrm{L})(\mathrm{n}=223)$ & $0.5(0.2-1.7)$ \\
\hline
\end{tabular}

*Differences in absolute frequencies correspond to missing values. 
Table 2. Prevalence of vitamin A deficiency among children analyzed by gender, maternal schooling and C-reactive protein. Goiânia, Goiás, $2013(n=228)$.

\begin{tabular}{l|c|c|c}
\multirow{2}{*}{ Variables } & Total & \multicolumn{2}{|c}{ Vitamin A deficiency* } \\
\cline { 3 - 4 } & $\mathrm{n}(\%)$ & $\mathrm{n}(\%)$ & $\mathrm{p}$-value** \\
\hline Total & $228(100,0)$ & $32(14.0)$ & - \\
\hline Gender & & & 0.414 \\
\hline Male & $115(50.4)$ & $14(12.2)$ & \\
\hline Female & $113(49.6)$ & $18(15.9)$ & \\
\hline Maternal scholing $(\mathrm{n}=225)$ & & & 0.027 \\
\hline$<9$ schooling years & $68(30.2)$ & $15(22.1)$ & \\
\hline$\geq 9$ schooling years & $157(69.8)$ & $17(10.8)$ & \\
\hline CRP $(\mathrm{mg} / \mathrm{L})(\mathrm{n}=223)$ & & & $<0.001$ \\
\hline$\leq 5$ & $192(86.1)$ & $19(9.9)$ & \\
\hline$>5$ & $31(13.9)$ & $12(38.7)$ &
\end{tabular}

*Serum retinol $<0.7 \mu \mathrm{mol} / \mathrm{L}$; ${ }^{* *}$ Pearson's $\chi^{2}$ test; CRP: C-reactive protein.

Table 3. Factors associated with the concentration of serum retinol among children assisted at the Basic Health Units of Goiânia, Goiás, 2013.

\begin{tabular}{|c|c|c|c|}
\hline Variables & $\beta^{*}$ & $95 \% \mathrm{Cl}$ & p-value \\
\hline Per capita income & 0.000 & $-0.000-0.000$ & 0.083 \\
\hline Maternal schooling & 0.021 & $0.007-0.035$ & 0.003 \\
\hline \multicolumn{4}{|l|}{ Treatment of drinking water } \\
\hline Inadequate & 1 & & \\
\hline Adequate & 0.091 & $-0.008-0.190$ & 0.070 \\
\hline \multicolumn{4}{|l|}{ Sanitary sewer } \\
\hline Without public network & 1 & & \\
\hline With public network & 0.030 & $-0.052-0.112$ & 0.468 \\
\hline \multicolumn{4}{|c|}{ Children with $<5$ years old in the house } \\
\hline 1 child & 1 & & \\
\hline$>1$ child & -0.083 & $-0.180-0.013$ & 0.091 \\
\hline Mother's age & 0.005 & $-0.001-0.010$ & 0.095 \\
\hline N. of prenatal appointments & -0.001 & $-0.016-0.014$ & 0.907 \\
\hline Weight at birth & -0.000 & $-0.000-0.000$ & 0.473 \\
\hline Body mass index/age & 0.012 & $-0.022-0.046$ & 0.496 \\
\hline Height/age index & 0.004 & $-0.031-0.039$ & 0.820 \\
\hline Age of weaning & 0.000 & $-0.000-0.001$ & 0.500 \\
\hline \multicolumn{4}{|c|}{ Vitamin $A$ and $D$ supplementation } \\
\hline Never used it & 1 & & \\
\hline Has used it or uses it & 0.0558 & $-0.059-0.171$ & 0.340 \\
\hline \multicolumn{4}{|l|}{ Diarrhea in the past 15 days } \\
\hline No & 1 & & \\
\hline Yes & -0.038 & $-0.133-0.057$ & 0.436 \\
\hline Hemoglobin & 0.092 & $0.049-0.134$ & $<0.001$ \\
\hline C-reactive protein & -0.020 & $-0.027--0.013$ & $<0.001$ \\
\hline
\end{tabular}

${ }^{*}$ Adjusted for gender and age; $95 \% \mathrm{Cl}$ : 95\% confidence interval 
hemoglobin there is an increment of $0.018 \mu \mathrm{mol} / \mathrm{L}$ and $0.049 \mu \mathrm{mol} / \mathrm{L}$, respectively, in the log of serum retinol of the studied children. As to CRP, there is a negative correlation with serum retinol concentrations; for each unit of CRP, there is a $0.017 \mu \mathrm{mol} / \mathrm{L}$ decrease in the retinol log. Approximately $16.5 \%$ of the variability of serum retinol concentrations in these children can be explained by these three variables. CRP has contributed the most to determine the serum retinol concentration in this sample, even after the exclusion of children with CRP $>10 \mathrm{mg} / \mathrm{L}$ (data not shown).

\section{DISCUSSION}

The prevalence of VAD found in this study was $14.0 \%$, which represents a moderate public health problem according to the criteria adopted by the $\mathrm{WHO}^{1}$. The median of serum retinol was within normal patterns, and higher concentrations of retinol were observed among children whose mothers had higher schooling, those with higher hemoglobin concentration and lower CRP concentration.

The prevalence of VAD was similar to that of studies conducted with children aged less than two years old in other regions of the country ${ }^{4-6}$. In Belo Horizonte, Minas Gerais, an analysis conducted in a UBS with children aged from 6 to 24 months

Table 4. Multiple linear regression models for the serum concentration of retinol of children assisted at Basic Health units of Goiânia, Goiás, 2013.

\begin{tabular}{|c|c|c|c|c|c|}
\hline Variables & Adjusted $\beta^{*}$ & $95 \% \mathrm{Cl}$ & $\mathrm{p}$-value & $\mathrm{R}^{2}$ & Standardized $\beta^{* *}$ \\
\hline Block I & & & & 0.0232 & \\
\hline Per capita income & 0.000 & $-0.000-0.000$ & 0.385 & & \\
\hline Maternal schooling & 0.018 & $0.003-0.032$ & 0.017 & & 0.158 \\
\hline Block II & & & & 0.0360 & \\
\hline \multicolumn{6}{|c|}{ Treatment of drinking water } \\
\hline Inadequate & 1 & & & & \\
\hline Adequate & 0.041 & $-0.061-0.143$ & 0.434 & & \\
\hline \multicolumn{6}{|c|}{ N. of children $<5$ years old } \\
\hline 1 child & 1 & & & & \\
\hline$>1$ child & -0.058 & $-0.154-0.038$ & 0.235 & & \\
\hline Mother's age & 0.003 & $-0.002-0.009$ & 0.249 & & \\
\hline Bloco III & & & & 0.1648 & \\
\hline Hemoglobin & 0.049 & $0.007-0.090$ & 0.022 & & 0.151 \\
\hline C-reactive protein & -0.017 & $-0.024--0.010$ & $<0.001$ & & -0.300 \\
\hline
\end{tabular}


old found prevalence of $17.7 \%{ }^{4}$. A population-based cross-sectional study conducted in Acrelândia, Acre, with children aged from 6 to 24 months old, found prevalence of $14.9 \%^{6}$, and in Viçosa, Minas Gerais, the prevalence was $9.6 \%{ }^{5}$ for children aged 12 to 20 months old. However, the prevalence of VAD found in this study was lower to that found in day care facilities of the city of Goiânia, Goiás, whose prevalence was $21.7 \%{ }^{3}$. This difference can be attributed to the prevalence of subclinical infection found in each study, being $13.9 \%$ in this study and $41.4 \%$ in the aforementioned analysis.

Even though the general prevalence of VAD in this study is $14.0 \%$, this prevalence was overestimated in $4.1 \%$ after excluding the children with subclinical infection $(\mathrm{PCR}>5 \mathrm{mg} / \mathrm{L})$. Similar overestimations in the real prevalence of VAD were found in the analyses by Queiroz et al. ${ }^{13}(2.0 \%)$ and Danneskiold-Samsøe et al. ${ }^{26}(5.5 \%)$, who used CRP $\geq 6 \mathrm{mg} / \mathrm{L}$ and CRP $>5 \mathrm{mg} / \mathrm{L}$ as cutoff points for infection, respectively.

Despite being the most used indicator to assess the nutritional status of vitamin A, the serum retinol concentration can be reduced in infectious processes, even if the vitamin stores in the liver are at normal levels. This reduction is owed to the fact that the retinol binding protein (RBP) is at a negative acute phase. This fact generates lower mobilization of vitamin A, not necessarily reflecting its defficiency ${ }^{23,24}$.

So, Thurnham et al. ${ }^{24}$ proposed the correction of the effects of subclinical infection when trying to estimate the prevalence of VAD in a population. Therefore, they suggest the exclusion of individuals with high values of acute and chronic phase proteins, such as CRP $>5 \mathrm{mg} / \mathrm{L}$ and alpha-1-acid glycoprotein $>1.0 \mathrm{~g} / \mathrm{L}$.

Maternal schooling was positively correlated with the concentration of serum retinol in this study. In literature, many studies have shown a strong connection between maternal schooling and the health of the child, especially concerning preventive (hygiene, immunization and diet) and curative care (handling diseases in the household and looking for care early ${ }^{27,28}$. According to Glewwe ${ }^{29}$, maternal schooling has influence on the health of the children in three aspects:

1. formal education transfers basic health-related knowledge for mothers-to-be at school;

2. reading and mathematics skills that women learn at school improve their ability to identify diseases and look for treatment for their children; they also improve the understanding of orientations passed on by health professionals; and

3. the women become more receptive to modern medicine.

Besides, maternal schooling can work on the health conditions of children only for elevating the socioeconomic status of the house. This happens because women with higher schooling earn more, marry men who also have higher schooling and, therefore, higher income, and live in better neighborhoods, with sanitary conditions. These factors influence the health of the child and, consequently, nutritional deficiencies ${ }^{27,28}$.

This finding is in accordance with that by Rohner et al. ${ }^{30}$. In a cross-sectional study conducted in the Philippines, they found a positive association between maternal schooling and VAD. Also, Yang et al. ${ }^{31}$ conducted a study in China and found a 
negative association between parental schooling and the risk of developing VAD. Even though it is a strong determinant of the reduction in serum retinol concentrations in international studies ${ }^{30,31}$, most Brazilian analyses that observed the association between maternal schooling and VAD did not find such an association ${ }^{13-15,18}$.

The levels of hemoglobin were also positively correlated with the serum retinol concentration in this study. This narrow association between VAD and anemia is demonstrated in epidemiological studies conducted in some countries ${ }^{32-34}$. According to Semba and Bloem ${ }^{32}$, vitamin A seems to be involved in the origin of anemia due to several biological mechanisms. This vitamin directly affects hematopoiesis, since it works on distinguishing the erythrocyte and on moving iron stores; it increases the resistance to infections, which could influence hematopoiesis. Kan et al. ${ }^{33}$ showed that the serum retinol concentration was positively correlated with the concentration of hemoglobin in children from Vietnam; then, Jafari et al. ${ }^{34}$ also demonstrated that this variable had a significant association with the concentration of hemoglobin, regardless of iron homeostasis.

In this study, the CRP concentration was negatively correlated with the concentration of serum retinol. And this relationship between VAD and infectious processes is clear in literature ${ }^{8,9}$. Pictures of frequent infections, especially those causing diarrhea and respiratory problems, may cause or worsen VAD in childhood, both by reducing dietary intake and the absorption of nutrients and by depleting body stores of this vitamin by increasing the catabolism and urinary excretion ${ }^{8,9}$. Besides, VAD is a risk factor for the development of infectious diseases, since it decreases the immune resistance to these conditions, thus creating a vicious cycle between VAD and infections among children?.

Similar results could be observed in other studies ${ }^{13,30,35}$. Pasricha et al. ${ }^{35}$ found a negative correlation between the serum concentration of retinol binding protein and CRP; Rohner et al. ${ }^{30}$ observed that children with inflammation (assessed by high concentrations of CRP and alpha-1-acid glycoprotein) demonstrated significant increase in the risk of VAD; and Hotz et al. ${ }^{36}$ found an inverse correlation between plasma retinol and CRP.

Some limitations in this study must be considered, such as the lack of data on the habitual intake of sources of vitamin A; the use of a sample of users in the health service, which does not allow the extrapolation of results for the general infant population of Goiânia; and, finally, the cross-sectional design of the study does not allow causality assumptions, so results must be interpreted carefully. In spite of that, it is important to mention that the results in this study reflect the situation of infants assisted in some UBSs of Goiânia, Goiás, and few months before the distribution of megadose of vitamin A. This information is important to monitor the effectiveness of the National Program of Vitamin A Supplementation in this city. 


\section{CONCLUSION}

It is concluded that VAD among one-year-olds assisted in UBSs of Goiânia is a moderate public health issue. The serum retinol concentration was positively correlated with maternal schooling and the concentration of hemoglobin; on the one hand, it was possible to observe the negative correlation between CRP and serum retinol concentrations. Preventive and control actions addressed to VAD which have an influence on the social health determinants and on the prevention of other nutritional deficiencies in childhood are essential to reduce this deficiency in that population.

\section{REFERENCES}

1. World Health Organization (WHO). Global prevalence of vitamin A deficiency in populations at risk 19952005: WHO Global Database on Vitamin A Deficiency. Geneva; 2009.

2. Brasil. Ministério da Saúde. Centro Brasileiro de Análise Planejamento. Pesquisa Nacional de Demografia e Saúde da criança e da mulher PNDS 2006: dimensões do processo reprodutivo e da saúde da criança. Série G. Estatística e Informação em Saúde. Brasília: Ministério da Saúde; 2009. Disponível em: http: / / bvsms.saude. gov.br/bvs/publicacoes/pnds_crianca_mulher.pdf (Acessado em 15 de maio de 2013).

3. Lobo LMC. Fatores relacionados aos níveis de retinol sérico em crianças de seis a 24 meses de creches municipais de Goiânia-Goiás [Dissertação de mestrado]. Goiânia: Faculdade de Nutrição da Universidade Federal de Goiás; 2013.

4. Barros ALA, Soares ADN, Pessoa MC, Teixeira RA, Beinner MA. Deficiência de vitamina a em crianças residentes na região metropolitana de Belo Horizonte, Minas Gerais. REME Rev Min Enferm 2010; 14(3) :386-93.

5. Netto MP, Rocha DS, Franceschini SCC, Lamounier JA. Fatores associados à anemia em lactentes nascidos a termo e sem baixo peso. Rev Assoc Med Bras 2011; 57(5): 550-8.

6. Garcia MT, Granado FS, Cardoso MA. Alimentação complementar e estado nutricional de crianças menores de dois anos atendidas no Programa Saúde da Família em Acrelândia, Acre, Amazônia Ocidental Brasileira. Cad Saúde Pública 2011; 27(2): 305-16.

7. Netto MP, Priore SE, Sant'ana HMP, Peluzio MCG, Sabarense CM, Franceschini SCC. Fatores associados à concentração de retinol sérico em lactentes. Rev Paul Pediatr 2012; 30(1): 27-34.

8. Miller M, Humphrey J, Johnson E, Marinda E, Brookmeyer R, Katz J. Why do children become vitamin A deficient? J Nutr 2002; 132(9 Suppl): 2867S-80S.

9. Stephensen CB. Vitamin A infection, and immune function. Annu Rev Nutr 2001; 21: 167-92.

10. Jiang JX, Lin LM, Lian GL, Greiner T. Vitamin A deficiency and child feeding in Beijing and Cuizhou, China. World J Pediatr 2008; 4(1): 20-5.

11. Martins MC, Santos LM, Assis AM. Prevalence of hypovitaminosis A among preschool children from northeastern Brazil, 1998. Rev Saúde Pública 2004; 38(4): 537-42.

12. Oliveira JS, Lira PIC, Osório MM, Sequeira LAS, Costa EC, Gonçalves FCLSP, et al. Anemia, hipovitaminose A e insegurança alimentar em crianças de municípios de Baixo Índice de Desenvolvimento Humano do Nordeste do Brasil. Rev Bras Epidemiol 2010; 13(4): 651-64.

13. Queiroz D, Paiva AA, Pedraza DF, Cunha MAL, Esteves GH, Luna JG, et al. Deficiência de vitamina A e fatores associados em crianças de áreas urbanas. Rev Saúde Pública 2013; 47(2): 248-56.

14. Miglioli TC, Fonseca VM, Gomes Junior SC, Lira PIC, Batista Filho M. Deficiência de Vitamina A em mães e filhos no Estado de Pernambuco. Ciênc Saúde Coletiva 2013; 18(5): 1427-40.

15. Ferraz IS, Daneluzzi JC, Vannucchi H. Vitamin A deficiency in children aged 6 to 24 months in Sao Paulo State, Brazil. Nut Res 2000; 20: 757-68. 
16. Midyat L, Kurugöl N, Aksit S, Tanrıverdi M, Yagc1 RV. Dietary vitamin A intake and serum retinol concentrations of preschool children from different socio-economical levels in Izmir, Turkey. Acta Pædiatr 2011; 100(7): e24-7.

17. Tansuğ N, Polat M, Çeşme S, Taneli F, Gözmen S, Tokuşoğlu O, et al. Vitamin A status of healthy children in Manisa, Turkey. Nutr J 2010; 9: 34.

18. Ramalho RA, Flores H, Accioly E, Saunders C. Associação entre deficiência de vitamina A e situação sociodemográfica de mães e recém-nascidos. Rev Assoc Med Bras 2006; 52(3): 170-5.

19. Brasil. Ministério da Saúde. Manual de Condutas Gerais do Programa Nacional de Suplementação de Vitamina A. Brasília: Ministério da Saúde; 2013.

20. Hulley SB, Cummings SR. Designing Clinical Research: an epidemiologic approach. Baltimore: Williams \& Wilkins; 1988.

21. Lohman TG, Roche AF, Martorell R. Anthropometric standardization reference manual. Illinois: Human Kinetics Books; 1988.

22. Gomes LF, Alves AF, Sevanian A, Peres CA, Cendoroglo MS, de Mello-Almada C, et al. Role of beta2-glycoprotein I, LDL-, and antioxidant concentrations in hypercholesterolemic elderly subjects. Antioxid Redox Signal 2004; 6(2): 237-44.

23. World Health Organization (WHO). Indicators for assessing Vitamin A Deficiency and their application in monitoring and evaluating intervention programmes. Geneva; 1996.

24. Thurnham DI, McCabe GP, Northrop-Clewes CA, Nestel P. Effects of subclinical infection on plasma retinol concentrations and assessment of prevalence of vitamin A deficiency: meta-analysis. Lancet 2003; 362(9401): 2052-8.

25. Victora CG, Huttly SR, Fuchs SC, Olinto MT. The role of conceptual frameworks in epidemiological analysis: a hierarchical approach. Int J Epidemiol 1997; 26(1): 224-7.

26. Danneskiold-Samsøe N, Fisker AB, Jørgensen MJ, Ravn $\mathrm{H}$, Andersen A, Balde ID, et al. Determinants of vitamin a deficiency in children between 6 months and 2 years of age in Guinea-Bissau. BMC Public Health 2013; 13: 172.

27. Burchi F. Child nutrition in Mozambique in 2003: the role of mother's schooling and nutrition knowledge. Econ Hum Biol 2010; 8(3): 331-45.
28. Abuya BA, Ciera J, Kimani-Murage E. Effect of mother's education on child's nutritional status in the slums of Nairobi. BMC Pediatr 2012; 12: 80.

29. Glewwe P. Why does mother's schooling raise child health in developing countries? Evidence from Morocco. J Hum Resour 1999, 34(1): 124-59.

30. Rohner F, Woodruff BA, Aaron GJ, Yakes EA, Lebanan MA, Rayco-Solon P, et al. Infant and young child feeding practices in urban Philippines and their associations with stunting, anemia, and deficiencies of iron and vitamin A. Food Nutr Bull 2013; 34(2 Suppl): S17-34.

31. Yang R, Li R, Mao S, Sun L, Huang X, Ji C, et al. The survey of serum retinol of the children aged $0 \sim 4$ years in Zhejiang Province, China. BMC Public Health 2007; 7: 264.

32. Semba RD, Bloem MW. The anemia of vitamin A deficiency: epidemiology and pathogenesis. Eur J Clin Nutr 2002; 56(4): 271-81.

33. Khan NC, Huan PV, Nhien NV, Tuyen LD, Pee S, Semba RD. Relationship of serum carotenoids and retinol with anaemia among pre-school children in the northern mountainous region of Vietnam. Public Health Nutr 2010, 13(11): 1863-9.

34. Jafari SM, Heidari G, Nabipoura I, Amirinejad R, Assadi M, Bargahi A, et al. Serum retinol levels are positively correlated with hemoglobin concentrations, independent of iron homeostasis: a population-based study. Nutr Res 2013, 33(4): 279-85.

35. Pasricha SR, Shet AS, Black JF, Sudarshan H, Prashanth NS, Biggs BA. Vitamin B-12, folate, iron, and vitamin A concentrations in rural Indian children are associated with continued breastfeeding, complementary diet, and maternal nutrition. Am J Clin Nutr 2011; 94(5): 1358-70.

36. Hotz C, Chileshe J, Siamusantu W, Palaniappan U, Kafwembe E. Vitamin A intake and infection are associated with plasma retinol among pre-school children in rural Zambia. Public Health Nutr 2012; 15(9): 1688-96.

Received on: 04/17/2014

Final version presented on: 08/20/2014

Accepted on: 10/01/2014 